\title{
AN APPRECIATION
}

\author{
Dorothy S. Severin \\ Liverpool University
}

The staged reading of Robert Potter and Pamela Howard's Celestina at the Almeida Theatre, Islington, London on Sunday 22 April 1990 was an exciting affair for the Celestina specialist. The outstanding English cast, led by Linda Polan as the bawd, managed to get inside the text to find the comedy, a feat which still eludes the recent Spanish casts which I have seen. Although director Pamela Howard admitted to me in private conversation that the abrupt changes of tone from high to low register in a single character presented the actors with problems within the context of British stage tradition, I thought that they solved this problem admirably and Polan in particular milked these abrupt transitions for their comic value. Sempronio (Ian Reddington) and Pármeno (Robert Hughes) were also fine comic turns (for example the "puta vieja" speech), and the two well-known actresses who played Elicia (Heather Tobias) and Areúsa (Julie Le Grand) gave a show-stealing rendition of their grotesque description of Melibea in the banquet scene. Kate Littlewood was 
also outstanding as a youngish Alisa, playing her as a brainless Sloane Ranger.

The stage version has boiled the several hours down to two-anda-half, thus some fairly severe abridgement has occurred. In the interest of maintaining dramatic tension the ending has been rearranged and Act XIX (the second night of love) has replaced Act XIV (the first), the Centurio subplot has been dropped, and Act XVI (Melibea overhears her parents) has been transposed to an earlier point before the first assignation of Act XII (and cut perhaps a bit too ruthlessly).

The most exciting aspect of this production was its improvised feel. The actors lumbering around on a hopelessly messy set (for another production, of Volpone) with their large scripts in hand, far from destroying the illusion, rather gave the feel of an authentic textual reading-out-loud session in the sixteenth century. My only cavil is that the adaptors wish to make some sort of point about the converso background of Rojas (who in a nice touch appears as a character entr'act, reading some of his prologal material). To that end they have filled in between scenes with 'dumb shows' (only described not seen) of inquisitorial barbarities etc., which surely if ever realized would only look like more Hispanophobic purveying of the Black Legend by a group of Anglos. And the one invented scene of a 'judaizante' Pleberio and Alisa surreptitiously celebrating Yom Kippur unintentionally created the opposite impression from the one presumably intended. It made the fairly innocent victim Pleberio look as though he were being punished for recent heresies, rather like those perpetuated by the guilty Celestina in the witchcraft scene.

The outstanding prose translation of the text by Potter and Howard soared above these attempts at interpretation and proved what we all know: that the young Rojas' converso background had turned him not into a 'judaizante,' but into a confirmed ironist and pessimist. 